\title{
Using Unmanned Helicopters to Assess Vegetation Cover in Sagebrush Steppe Ecosystems
}

\author{
Robert P. Breckenridge, ${ }^{1}$ Maxine Dakins, ${ }^{2}$ Stephen Bunting, ${ }^{3}$ Jerry L. Harbour, ${ }^{4}$ and Randy D. Lee ${ }^{5}$ \\ Authors are ${ }^{1}$ Environmental Scientist and ${ }^{5}$ Geospatial Scientist, Idaho National Laboratory, Idaho Falls, ID 83415, USA; ${ }^{2}$ Associate Professor, \\ Environmental Science Program, and ${ }^{3}$ Professor, Department of Rangeland Ecology and Management, University of Idaho, Moscow, ID 83844, USA; and \\ ${ }^{4}$ Senior Scientist, Epsilon System Solutions, Inc., Albuquerque, NM 87106, USA.
}

\begin{abstract}
Evaluating vegetation cover is an important factor in understanding the sustainability of many ecosystems. Remote sensing methods with sufficient accuracy could dramatically alter how biotic resources are monitored on both public and private lands. Idaho National Laboratory (INL), in conjunction with the University of Idaho, evaluated whether unmanned aerial vehicles (UAVs) are sufficiently accurate and more efficient than the point-frame field method for monitoring vegetative cover and bare ground in sagebrush steppe ecosystems. These values are of interest to land managers because typically there are limited natural resource scientists and funding for comprehensive ground evaluations. In this project, unmanned helicopters were used to collect still-frame imagery to determine vegetation cover during June and July 2005. The images were used to estimate percent cover for six vegetative cover classes (shrub, dead shrub, grass, forbs, litter, and bare ground). Field plots used to collect imagery and onthe-ground measurements were located on the INL site west of Idaho Falls, Idaho. Ocular assessments of digital imagery were performed using SamplePoint, and the results were compared with field measurements collected using a point-frame method. The helicopter imagery evaluation showed a high degree of agreement with field cover class values for grass, litter, and bare ground and reasonable agreement for dead shrubs. Shrub cover was often overestimated, and forbs were generally underestimated. The helicopter method took $45 \%$ less time than the field method. This study demonstrates that UAV technology provides a viable method for monitoring selective types of cover on rangelands and could save time and resources.
\end{abstract}

\section{Resumen}

Evaluar la cobertura vegetal es un importante factor para entender la sustentabilidad de muchos ecosistemas. Métodos de teledetección con suficiente precisión pueden considerablemente alterar la manera en como los recursos bióticos son monitoreados tanto en propiedad privada y pública. El laboratorio Nacional de Idaho (INL), en conjunto con la universidad de Idaho, evaluaron si vehículos aéreos no tripulados (UAVs) son suficientemente precisos y más eficientes que los métodos de campo basados en punto de referencia para monitorear la cobertura de las vegetación y el suelo desnudo en los ecosistemas de pastizales de Artemisia. Estas evaluaciones son de interés para los manejadores de tierra ya que normalmente hay pocos científicos dedicados al estudio de los recursos naturales así como escasos recursos monetarios para evaluaciones integrales. En este proyecto, helicópteros no tripulados fueron usados para recolectar imágenes usadas para determinar la cobertura vegetal durante junio y julio de 2005. Las imágenes fueron usadas para estimar el porcentaje de cobertura de seis clases de cubierta vegetal (arbustos, arbustos muertos, pastos, herbáceas, hojarasca y suelo desnudo). Parcelas de campo que fueron usadas para recolectar las imágenes así como las mediciones en campo fueron localizadas en el sitio INL al oeste de Idaho Falls, Idaho. Evaluaciones oculares de imágenes digitales fueron realizadas usando SamplePoint y los resultados fueron comparados con las mediciones de campo recolectadas usando el método de point-frame. La evaluación de las imágenes recolectadas por el helicóptero mostró un alto grado de correlación con respecto a las evaluaciones de campo para pastos, hojarasca, y suelo desnudo, y una razonable relación para plantas muertas. Las cobertura de los arbustos fue regularmente sobrestimado y para las herbáceas fueron generalmente subestimadas. El método del helicóptero tomo $45 \%$ menos tiempo que el método de campo. Este estudio demostró que la tecnología UAV proporciono un método viable para monitorear los tipos selectivos de cobertura en los pastizales y podría salvar tiempo y recursos.

Key Words: imagery, monitoring, rangelands, SamplePoint, unmanned aerial vehicle

\section{INTRODUCTION}

Work was supported through Idaho National Laboratory's Laboratory Directed Research \& Development Program under DOE Idaho Operations Office Contract DE-AC0705ID14517.

At the time of research, Breckenridge was Manager, Ecological Sciences Department, Idaho National Laboratory, Idaho Falls, ID 83415, USA.

Correspondence: Robert P. Breckenridge, Idaho National Laboratory, P0 Box 1625, Idaho Falls, ID 83415-2213, USA. Email: Robert.Breckenridge@inl.gov

Manuscript received 18 February 2010; manuscript accepted 26 February 2012.
One of the most observed features of an ecological community by an ecologist is its physical structure (Smith 1990). Vegetation cover is an important part of this structure (Bonham 1989) and is an indicator of rangeland health (Society for Range Management 1995; US Department of the InteriorBureau of Land Management [USDI-BLM] 1997; Pyke et al. 2002; Pellant et al. 2005). Cover data provide important 
information about ecological structure and processes, such as nutrient cycling (National Research Council 1994; Carroll et al. 1999; Pyke et al. 2002; Crawford et al. 2004; Pellant et al. 2005), fuel management (Bunting 2002), and desertification (Mouat and Hutchinson 1995).

Vegetation cover is defined as the proportion of ground covered, when viewed from directly overhead, from the outline of the aerial parts of a plant (Brower et al. 1990). This material can be either live or dead vegetation (grass, forbs, shrub, dead shrub, litter) or, in cases where no vegetation is present, bare ground or rock. For this reason, unmanned aerial vehicles (UAVs) may provide an effective near-earth platform for collecting aerial imagery in an overhead position that is near nadir (the point directly above an observation).

UAVs provide an alternative to manned aircraft and have become an established remote sensing technology to collect near-earth data for biotic resource management (Rango et al. 2009). Collecting data to evaluate vegetation cover on federal, state, and private lands in the western United States is a monumental task where typically not enough field specialists and funding exist to conduct ground surveys. Manned aircraft have historically been used to support monitoring activities on large areas of public lands, but the safety of staff flying in the vehicles has become a major concern (Zager 2006; National Transportation Safety Board 2010). Near-earth sensing aircraft can be flown using remote-controlled or autonomous navigational systems and can carry various sensors to capture imagery of the resources on the ground (Booth and Tueller 2003). UAVs do have some potential limitations, however, such as cost, image accuracy at the submeter level (Booth et al. 2006b), and susceptibility to weather conditions (e.g., cloud cover; Hardin et al. 2007; Rango et al. 2009). They also have payload limitations, so sensors and cameras need to be relatively light $(<6.8 \mathrm{~kg}$ for this study). For this study, the Idaho National Laboratory (INL) has an approved Federal Aviation Administration (FAA) certification to fly camera-on-board UAVs. Obtaining proper certification is important and needs to be considered and discussed with the regional FAA prior to any UAV flights.

This study specifically evaluated five different types of vegetation cover and bare ground in sagebrush communities. First, sagebrush communities are regarded by many as steppe or shrub steppe because of grasses that are valuable as forage to wildlife and grazers (Daubenmire 1970; Brown 1982). Forbs are another important cover class because of their forage value to wildlife (Connelly et al. 2000; Pedersen et al. 2003) and nutrient cycling (Smith 1990). The amounts of dead shrub and litter are important factors for both fire-fuel assessment and as deterrents against wind and rain erosion (Pyke et al. 2002; Pellant et al. 2005). Finally, bare ground has been identified by several different groups of rangeland scientists as one of the most important indicators for assessing long-term sustainability of western lands because it shows site susceptibility to accelerated wind and water erosion and enhances evaporation (Pyke et al. 2002; Maczko et al. 2004; Pellant et al. 2005). Both the amount (percent) of bare ground and the overall size of the bare ground patches are important factors to assess. Pyke et al. (2002) suggest that 20-30\% bare ground should be expected on sagebrush steppe rangelands and that bare patches should be less than $20-30 \mathrm{~cm}$ in diameter, with the occasional $30-\mathrm{cm}$ patch associated with shrubs.

In general, suitable sagebrush steppe habitat is dominated by a canopy of sagebrush (Pedersen et al. 2003). The absolute and relative amounts of sagebrush, grasses, and forbs on a specific site vary with the taxa of sagebrush (Artemisia ssp.), the ecological site potential, and the habitat's condition (Connelly et al. 2000). Sagebrush cover may reach $30-40 \%$ with a decline in herbaceous production and no recruitment of herbaceous seedlings. The continued increase in brush cover eventually leads to the reduction of understory plants (i.e., forbs and grasses; Anderson et al. 1996). In Wyoming's case, big sagebrush (Artemisia tridentata ssp. wyomingensis) ${ }^{1}$ understory production begins to decline when sagebrush cover is between $12 \%$ and $15 \%$, depending on site-specific features (Anderson et al. 1996). The importance of the forb component varies across the big sagebrush steppe communities. Forb richness increases with increasing soil moisture, so big sagebrush steppe has a diverse array of associated forbs (Bunting 2002).

Sagebrush steppe ecosystems often go through different phases of a community-from grasslands to shrublands with numerous vegetation states, including extensive grasses; mixtures of grasses, forbs, and sparse shrubs; and dense shrub cover (Walker 1993; Colket 2003). Cover in a sagebrush steppe ecosystem can be impacted by fire (Bunting et al. 1987; Keeley 2006), invasive species (Bunting 2002), and grazing intensity (Knick and Rotenberry 1995).

Vegetation cover is usually determined using one of several field methods, such as line-transect or quadrant sampling (Bonham 1989; Brower et al. 1990). The accuracy of conventional ground-cover methods compared with emerging automated methods has been evaluated by Booth and others (Booth and Tueller 2003; Booth et al. 2006b). Booth et al. (2006b) reported that conventional techniques have a significantly greater correlation $(\geq 92 \%$ agreement of measured to known) than measurements from algorithms in a software system called VegMeasure $(70 \%$ agreement; Johnson et al. 2003). The critical factor influencing the accuracy of the pointsampling method was the area of the contact point for the given method (Booth et al. 2006b). This supports the findings of others that using very fine point sampling techniques over fairly large areas yields the greatest measurement accuracy (Cook and Stubbendieck 1986).

This study was designed to evaluate the feasibility of using UAV technology and image-processing software to collect useful vegetation data on rangelands. The objectives of the study were to 1) assess the feasibility of using a UAV helicopter to collect imagery useful in the assessment of selected vegetation cover classes on rangelands, 2) compare the relative accuracy of the vegetation cover class values collected and processed from UAV technology with vegetation cover class values from field measurements, and 3) compare the level of effort (amount of time) for collecting vegetation cover class data from UAV and field methods.

\footnotetext{
The scientific names used are taken from a list of common plants on the INL site (Forman and Hafla 2009).
} 


\section{METHODS}

\section{Study Area and Design}

INL lands are federal lands managed by the US Department of Energy and occupy over $2300 \mathrm{~km}^{2}$ of sagebrush steppe vegetation. One of its research, development, and demonstration missions is to study applications for emerging UAV technology (Gatens 2010). The laboratory is located west of Idaho Falls, Idaho, in a semiarid section of the Upper Snake River Basin and is the largest of the few protected sagebrush steppe reserves (Anderson et al. 1996). INL is a semiarid cold desert environment with average annual temperature of $5.6^{\circ} \mathrm{C}$, with a frost-free period of about 90 days (Anderson et al. 1996). The mean annual precipitation is only about $220 \mathrm{~mm}$ (Anderson et al. 1996). This study used INL's sagebrush steppe ecosystem as the research site (lat $43^{\circ} 32^{\prime} \mathrm{N}$, long $112^{\circ} 57^{\prime} \mathrm{W}$ ).

INL's landscape is dominated by a sagebrush steppe ecosystem with the unique aspects of a high-elevation, cold desert ecosystem (Whitford 1986; Rickard et al. 1988). The most common shrubs at INL are Wyoming big sagebrush and Basin big sagebrush (A. tridentata ssp. tridentata; Anderson et al. 1996; Mahalovich and McArthur 2004). Grasses on the INL site are a mixture of native species, nonnative introduced species that are used for revegetation projects (e.g., crested wheatgrass), and invasive species such as cheatgrass. The most common native grasses include thickspike wheatgrass (Elymus lanceolatus), bottlebrush squirreltail (Elymus elymoides), and Indian ricegrass (Achnatherum hymenoides; Anderson et al. 1996).

For this study, we used both plots and subplots. Each of the seven plots was located in a different area, and each had four subplots. Field values for cover classes in this study were collected at the subplot level and used as the standards for comparison with imagery data collected from the UAV helicopter. Accuracy was evaluated by analyzing the paired differences between field values and imagery values obtained from the seven study plots.

\section{Study Plot Selection and Design}

Data collection occurred on the INL site during the summer of 2005. Field plots were established within an area where a UAV runway had been established and a permit to fly under a Federal Aviation Administration-Certification of Authorization (FAA-COA) had been obtained. (The FAA-COA is needed in all situations where an autopilot system is used for navigation [FAA 2008]). Plots were established in seven locations around the runway (see Fig. 1) to accommodate the helicopter's flight restrictions. The specific locations were randomly selected in areas that represented the diversity of vegetation in both sagebrush- and grass-dominated communities typical of sagebrush steppe ecosystems. All the plots were located in the same soil series and had a soil Munsell color of 10YR 6/2. The field plots selected for this study were chosen to represent the high degree of cover diversity found on the INL site. Some of the plots were very high in forb cover and low in shrub cover (see field plots 1 and 2), others had major components of rhizomatous or bunch grasses (see field plots 4 , 5 , and 6), and others had vegetation and bare ground with a higher amount of pebbles and rock fragments due to wind

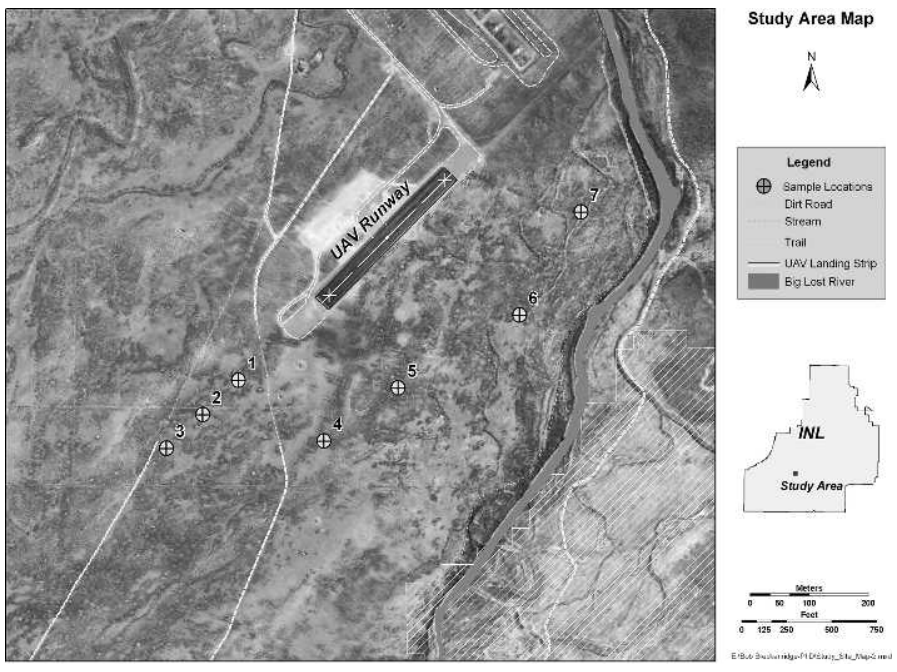

Figure 1. Map showing the location of the INL unmanned aerial vehicle runway, seven study plots, and study area on the laboratory site.

erosion (see field plot 7). This high degree of cover diversity allowed UAV technology to be evaluated under a wide variety of conditions.

Seven field plots were randomly established in the early spring by locating the northwest corner of each field plot and laying out four $3 \times 4 \mathrm{~m}$ subplots within each field plot location. The design of a rectangle was selected over a square because Brower et al. (1990) found that rectangular plots generate better results than other shapes for sampling plants. To identify the shapes of the subplots from the air, each corner of a subplot was marked by a 30.4-cm plastic paint bucket lid mounted on a $2.5 \mathrm{~cm} \times 5.1 \mathrm{~cm} \times 1.2 \mathrm{~m}$ wooden stake with two screws. Orange lids equal to the field plot number (e.g., field plot 7 had seven lids [shown in black in Fig. 2]) were located on each plot. Large field plot numbers were sprayed on the lids so that they could be viewed in the imagery at different heights above ground level (AGL). (The AGL designation is used with UAV flights because it provides an accurate representation of the height of the actual flight above the ground where elevation can vary in uneven terrain.) The paint bucket lid setup proved to be a very stable design and was an effective way to view the plots from the helicopters. Even with spring gusts of up to $97 \mathrm{~km} / \mathrm{h}$, only three of the 40-plus lids needed to be reattached.

\section{Image Acquisition}

Imagery was acquired in both late June and early July 2005 to evaluate the difference between mid- and peak-growing seasons. The UAV was an X-Cell 60 model helicopter made by Miniature Aircraft carrying a micro four-megapixel, Olympus Stylus, digital point-and-shoot camera. The cost of the UAV and camera system used in this study was about $\$ 5,000$. The camera was mounted on an aluminum frame located under the nose of the helicopter. The camera captured nadir images when the helicopter was in a stable hovering position. An operator acquired images by remotely triggering the camera. Because UAV helicopter technology was relatively new, there was very limited information from other studies on the optimum height (AGL) for collecting imagery. During 


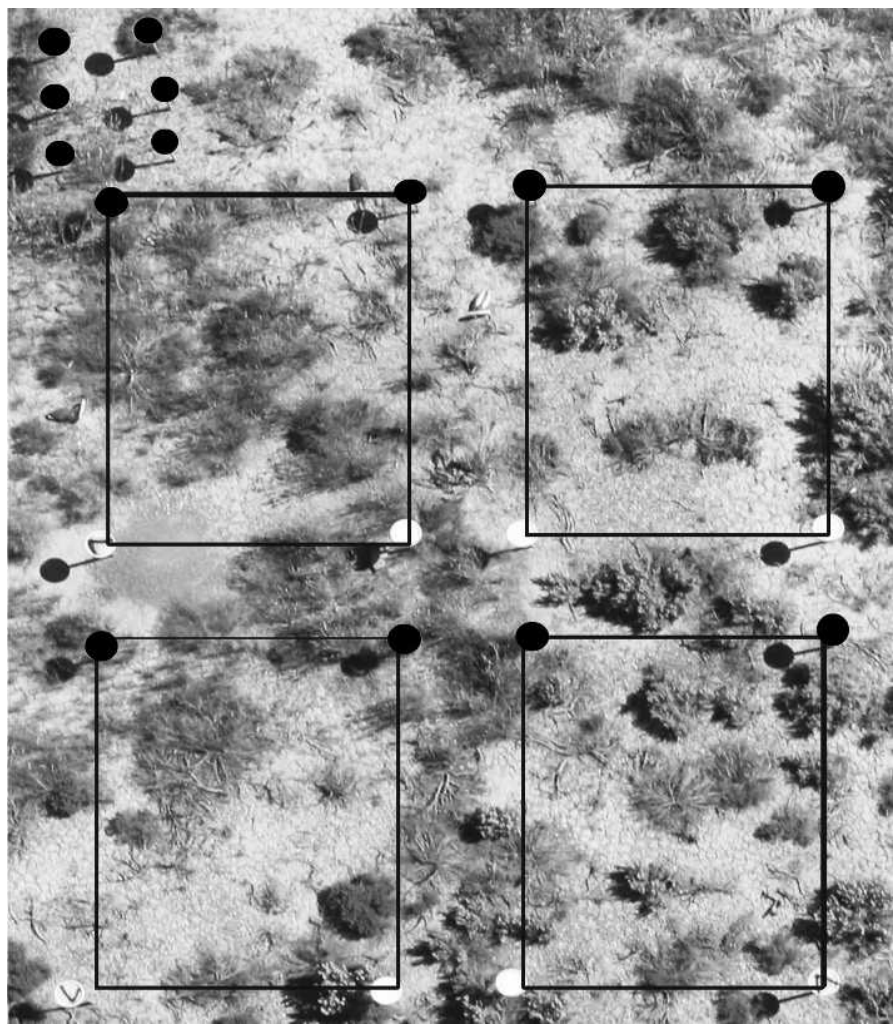

Figure 2. Sample plot design for unmanned vehicle image collection and analysis. This image shows the layout of plot 7 with its four $3 \times 4 \mathrm{~m}$ subplots. Note: The number of orange lids in upper left (NW) corner identifies the plot number (in this figure, plot 7).

preliminary testing, the UAV was flown at heights of 6-30 m AGL. Based on this test, imagery was collected at average heights of 11-15 $\mathrm{m}$ AGL, which allowed the entire subplot to be collected in one frame.

To position the helicopter directly over a subplot, two methods were tried. First, a through-the-lens video system was mounted onto the camera, and the operator on the ground viewed the plot using a $25-\mathrm{cm}$ portable screen. This method proved not to be effective because the field of view for the video was too restricted, making it difficult to locate the subplots. Also, the video screen was difficult to see and read when working in direct sunlight.

A second method proved to be effective and quick. This approach used two observers with flags located at adjacent sides of each plot. The flag persons signaled the location of the helicopter by holding the flag left, right, or straight up (meaning the helicopter was located over the center of the subplot). The camera operator relayed location information to the helicopter pilot. The information from the flag holders was used to ensure that the helicopter was centered over the subplot when acquiring pictures. Some experience was needed by both the camera and helicopter operators to center the helicopter over the subplot when winds exceeded $16 \mathrm{~km} / \mathrm{h}$. The helicopter was able to be flown in winds up to $25 \mathrm{~km} / \mathrm{h}$, but landing was difficult and required a high degree of skill by the pilot.

The best approach for developing a field heliport was to lay down a $1 \times 2 \mathrm{~m}$ mat in a clear area near the plot and use this as the takeoff and landing area. After each flight, the pictures were downloaded from the camera to a laptop, and the operators immediately evaluated the photographs to ensure that good images were acquired for analysis. The helicopter had a flighttime limitation of about $15 \mathrm{~min}$ because of its fuel capacity. On average, 30 images were collected over each field plot during flights that averaged $5 \mathrm{~min}$. Time required to collect images was recorded and used in the cost analysis.

\section{Field Data Collection}

Field cover values were collected immediately following the second set of flights during the second week of July 2005. Recording data from the plots earlier would have resulted in compaction of the vegetation. The subplots were sampled manually using a point-frame method (Floyd and Anderson 1982). The frame had a rectangular design of $0.5 \times 1 \mathrm{~m}$. A rectangle with sides in a 1:2 ratio was used because this shape yields better results than other shapes for sampling plants (Brower et al. 1990). At each sample location, two $0.5 \times 1 \mathrm{~m}$ areas were sampled by flipping the frame over after reading the first frame. The point-frame method used two sets of thin flyfishing backing line (bright orange) superimposed over each other $5 \mathrm{~cm}$ apart. The frame was typically located about $1.2 \mathrm{~m}$ above the ground, and the observer looked down between the two sets of strings and aligned them like crosshairs in a rifle scope. One hundred points were read for each frame.

A numbered $1 \times 1 \mathrm{~m}$ grid was established over each of the $3 \times 4 \mathrm{~m}$ subplots. Random numbers were used to select six of the twelve $1-\mathrm{m}^{2}$ quadrants as the sampling locations to be read with the point frame. Thus, $50 \%$ of each subplot was read.

The observers had field experience in assessing vegetation on rangelands. In order to ensure that high-quality data were collected, a very experienced plant science researcher trained the observers until there was $>95 \%$ agreement in point-frame results obtained by both the observer and the trainer.

\section{Image Manipulation and Processing}

For each plot, the clearest and nearest to nadir images were selected for analysis. Each image was rotated using Corel PHOTO-PAINT (Version 10) to the same directional orientation and cropped to the smallest rectangle possible that fit over the plot. This was done by rotating the image and lining up the longest side of the rectangle with a horizontal axis. Evaluation of the images was not done at the pixel level (usually assessments were on a four- to six-pixel spot); thus, evaluating resampling techniques during rotation was not a major concern. The cropped images were then imported into ERDAS Imagine (Version 8.6), a geographic information system imageprocessing software package. The images were aligned with the Image Geometric Correction subroutine. One image from each plot was selected as the base image or template. The other images for the plot were tied to the first by establishing points on the ground that could be identified in each image. The rotated, cropped, and matched images were then imported into SamplePoint image analysis software.

SamplePoint, a software program developed at the USDAARS in Cheyenne, Wyoming, was used to assess vegetation cover on each image (Booth et al. 2006a). SamplePoint overlays a grid over an image and allows the observer to identify the 


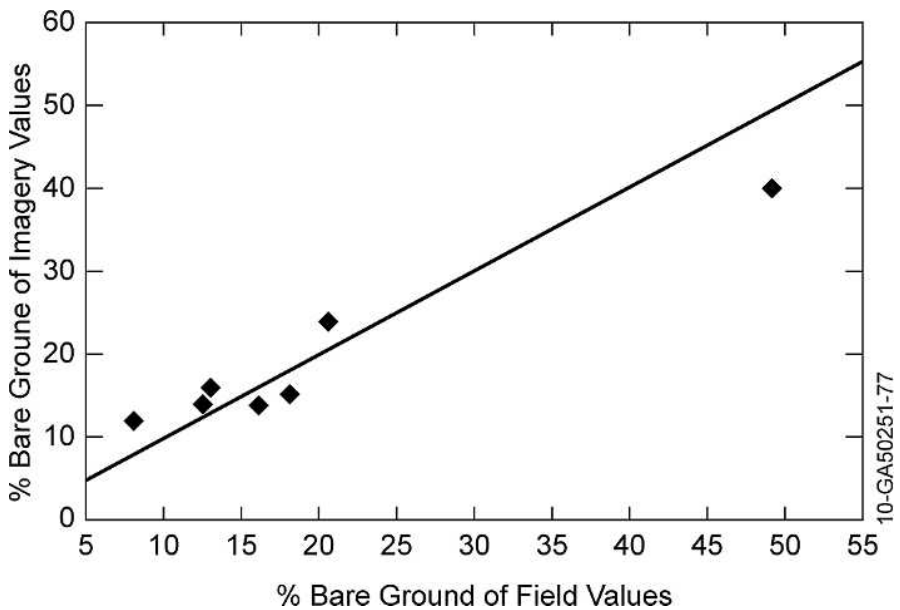

Figure 3. Imagery and field values for seven field plots for bare ground collected in July at $\approx 11 \mathrm{~m} \mathrm{AGL}$.

type of cover under the point that is under consideration. For this evaluation, a $10 \times 10$ grid (100 locations) was overlaid on each subplot image. At every grid point, the cover class was identified as one of eight classes (i.e., shrub, dead shrub [partial or entire dead plant material], grass, forb, litter, bare ground, shadow, or outside). If the cover class at a grid point could not be determined because of shadows or the vegetation fell outside the corners of the plots, it was recorded as either a shadow or outside. Imagery was read using the SamplePoint program by an experienced field observer. The time required to read an image was recorded, and an average value was used in the cost analysis discussed later in this article. Two weeks of SamplePoint training is not included in the cost analysis.

\section{Data Analysis}

Multiple analyses were conducted to assess how well the UAV imagery method compared to the field method for assessing percent cover for the six vegetation classes. An assumption made for this study is that the field method of estimating percent cover is most representative of the true values and is considered the standard against which the imagery values are compared.

Statistical assessments were conducted to evaluate how well the imagery method compared to the field method. Relative accuracy in measurement is assessed by considering the two component parts of measurement error: precision and accuracy (also called bias; Blackwood and Bradley 1991). Precision was measured first by comparing variances between the methods; accuracy was then assessed by using paired $t$ tests (Grubbs 1973). Before running the statistical tests, the assumption of normality was checked by examining the normal probability plots and histograms for the plot data. Once the normality assumption was verified, the variance caused by the measurement method (field or imagery) was separated from other sources of variability (e.g., among vegetation classes). In evaluating results, $P \leq 0.05$ was considered significant. Statistical analyses were conducted on the imagery and field data using Statistica (Version 7.1). Scatter plots were used to compare the results of the UAV and field methods for the six cover classes (Breckenridge 2007).

\section{RESULTS}

Scatter plots were generated with lines of perfect fit to evaluate the relationship between field and imagery values (Breckenridge 2007). The scatter plot for bare ground for July 2005, flown at $11 \mathrm{~m} \mathrm{AGL}$, is shown in Figure 3. The seven data points represent the seven different field plots. The data show that the amount of bare ground varied between $8 \%$ and $48 \%$ for the different field plots.

Table 1 shows the mean values for the imagery and field data and the results of the statistical evaluations for both precision and accuracy for the June and July 2005 data collections. In presenting and discussing results, we will address the July 2005 results first because, since the field data were collected to minimize impact to the field plots, these two data sets are more temporally related. The June 2005 data will then be presented and discussed; however, there was almost a month of growth between the June 2005 imagery and the July 2005 field values, and for some of the early season forbs, senescence occurred in the phenology of the plant communities.

\section{Evaluation of Precision Between Methods and Normality}

The distribution of the data appeared to satisfy the assumption of normality (Pitman 1939). The conclusion from the evaluation of the variances is that while there are limited cases where there are statistically significant differences in variances

Table 1. June and July 2005 INL field and imagery values. ${ }^{1}$

\begin{tabular}{|c|c|c|c|c|c|c|c|c|c|c|c|c|}
\hline \multirow[b]{2}{*}{$\begin{array}{l}\text { Cover } \\
\text { class }\end{array}$} & \multicolumn{6}{|c|}{ June } & \multicolumn{6}{|c|}{ July } \\
\hline & $n$ & $\begin{array}{c}\text { Mean imagery } \\
\text { values (SD) }\end{array}$ & $\begin{array}{c}\text { Mean field } \\
\text { values (SD) }\end{array}$ & $\begin{array}{c}\text { Test of equality } \\
\text { of variances } \\
(P \text { value })\end{array}$ & $\begin{array}{c}\text { Mean } \\
\text { difference } \\
(S D)\end{array}$ & $\begin{array}{l}\text { Test of means } \\
\text { of differences } \\
\text { ( } P \text { value })\end{array}$ & $n$ & $\begin{array}{c}\text { Mean imagery } \\
\text { values } \\
\text { (SD) }\end{array}$ & $\begin{array}{c}\text { Mean field } \\
\text { values (SD) }\end{array}$ & $\begin{array}{c}\text { Test of equality } \\
\text { of variances } \\
(P \text { value })\end{array}$ & $\begin{array}{c}\text { Mean } \\
\text { difference } \\
(\mathrm{SD})\end{array}$ & $\begin{array}{c}\text { Test of means } \\
\text { of differences } \\
(P \text { value })\end{array}$ \\
\hline Shrub & 4 & $12.2(3.0)$ & $10.1(3.0)$ & 0.988 & $2.2(3.6)$ & 0.319 & 7 & $22.0(11.2)$ & $12.7(4.8)$ & 0.008 & $9.2(7.4)$ & 0.017 \\
\hline Dead shrub & 4 & $6.2(3.9)$ & $7.7(4.4)$ & 0.780 & $-1.5(2.4)$ & 0.302 & 7 & $8.5(3.6)$ & $10.1(5.0)$ & 0.372 & $-1.6(3.7)$ & 0.299 \\
\hline Grass & 4 & $26.3(17.9)$ & $31.2(10.5)$ & $<0.001$ & $-4.9(7.4)$ & 0.275 & 7 & $28.0(13.1)$ & $27.0(13.6)$ & 0.890 & $1.0(7.4)$ & 0.735 \\
\hline Litter & 4 & $9.5(2.6)$ & $9.5(3.1)$ & 0.581 & $0.0(5.5)$ & 0.990 & 7 & $9.9(1.9)$ & $9.9(3.5)$ & 0.171 & $0.0(3.0)$ & 0.962 \\
\hline Bare ground & 4 & $24.5(9.4)$ & $14.5(5.4)$ & 0.246 & 10.0 & 0.037 & 7 & $19.0(10.0)$ & $19.8(13.9)$ & 0.045 & $-0.8(5.1)$ & 0.690 \\
\hline
\end{tabular}

${ }^{1}$ Values in large, bold type are significant at $P<0.05$. 
between methods, there were not enough cases to indicate a difference in precision between the two measurement methods.

\section{Evaluation of Accuracy Between Methods}

The July 2005 helicopter data show a significant difference in accuracy between methods only for shrub $(P=0.017$; see Table 1). For the June 2005 helicopter data, there was a significant difference between methods for bare ground $(P=0.037)$; forbs were marginally significant $(P=0.073)$. A possible explanation for this difference could be the monthlong interval between the imagery and field collection dates. For the bare ground assessment, the grasses and shrubs had not yet reached their full growth for the year; thus, the imagery values collected in June 2005 show a higher value for bare ground by almost $10 \%$. For the other four cover classes (i.e., shrub, dead shrub, grass, and litter), there were no significant differences.

\section{Evaluation of Time Required to Collect Data}

An assessment was also conducted of the times required to collect the imagery and field data. The time required to set up the field plots for the imagery analysis $(\sim 5 \mathrm{~h})$ was a little more than the time to set up for the field evaluation $(\sim 4 \mathrm{~h})$. It took about $8 \mathrm{~h}$ total to set up the UAV, conduct safety checks, collect and download the imagery, and then pack away the UAV. There were four people involved in collecting the imagery (i.e., helicopter pilot, camera operator, and two flag persons); thus, the total time to collect the imagery data was 32 person-hours. The field collection method was much more time consuming. It took about $1.25 \mathrm{~h}$ to sample $50 \%$ of each of the subplots. To sample all 28 subplots from the seven field plots, it took about $36 \mathrm{~h}$. Field sampling requires two people-one to read the plot and one to record the observation. Thus, the total time to collect the field data was 72 person-hours.

The imagery analysis took about $12.5 \mathrm{~min}$ total per subplot to process the image, get it ready to be imported into SamplePoint, and read the image. One of the most difficult tasks with the UAV process was selecting the best image for analysis. It took 5-6 min to read each subplot image. The data analysis time for both the imagery and the field plots was about 30 min per plot. A Microsoft Access database was used to store and query the two different data sets. The time required to report on the cover classes once the data were in the database was about $30 \mathrm{~min}$ per plot for both imagery and field data. These times are summarized in Table 2.

\section{DISCUSSION}

\section{Impact of Phenological Time on Imagery Results}

For the July 2005 data, the imagery was collected within a week of the field data. There was very good comparison in mean values between imagery and field values for grass, litter, and bare ground and, to a lesser extent, dead shrub. The shrub difference was statistically significant $(P=0.017)$, while the forbs was marginally significant $(P=0.061)$. It appears that the observer overestimated the areas with shrub cover that were identified as forbs in the field (see Fig. 4). The fact that at the subplot level only $50 \%$ of the field plot was measured could also have impacted the amount of shrubs. If just one or two
Table 2. Comparison of times required for collection of UAV and field data sets.

\begin{tabular}{lcc}
\hline \multicolumn{1}{c}{ Activity } & Imagery method $(\mathrm{h})$ & Field method $(\mathrm{h})$ \\
\hline Plot setup & 5 & 4 \\
Data collection & 32 & 72 \\
Image processing & 5.8 & - \\
Data analysis & 3.5 & 3.5 \\
Reporting & 3.5 & 3.5 \\
Total time & 49.8 & 83 \\
\hline
\end{tabular}

shrubs were missed during field sampling, this would make a large difference between the field and imagery values. These results suggest that the relative accuracy of UAV technology when compared to more conventional field data is good for measuring litter, grass, and bare ground on rangelands.

The significant difference for the shrub data may have been caused by the difficulty in identifying the forbs that were growing underneath and around the edges of the shrubs in the remotely sensed imagery. Often in rangelands, forbs will grow under shrubs because there is greater moisture and nutrients and the shrubs provide protection from grazers. Because many desert shrubs serve as islands of fertility (Carroll et al. 1999) and provide protection for forbs, it can be difficult to differentiate between the two without making observations on the ground. Also, many of the smaller forbs had passed their peak growth period, and some were senescing; therefore, the shape and color were difficult to differentiate from other cover classes (i.e., shrubs) with the then current imagery quality and resolution (four megapixels). Senescence also made it difficult to differentiate between some of the forbs and grasses in the imagery. It may be possible to resolve this issue by using a higher-resolution camera and collecting the imagery closer to the peak growing season. Thus, timing of collecting imagery for rangelands is an important factor that needs to be evaluated and considered when collecting and comparing aerial imagery with field data (Rango 2009). For areas around INL, the best window is probably between the end of June and the first week of July. This could differ slightly, depending on weather conditions as well as on whether a study's objectives were focused at a species level or on a functional group assessment.

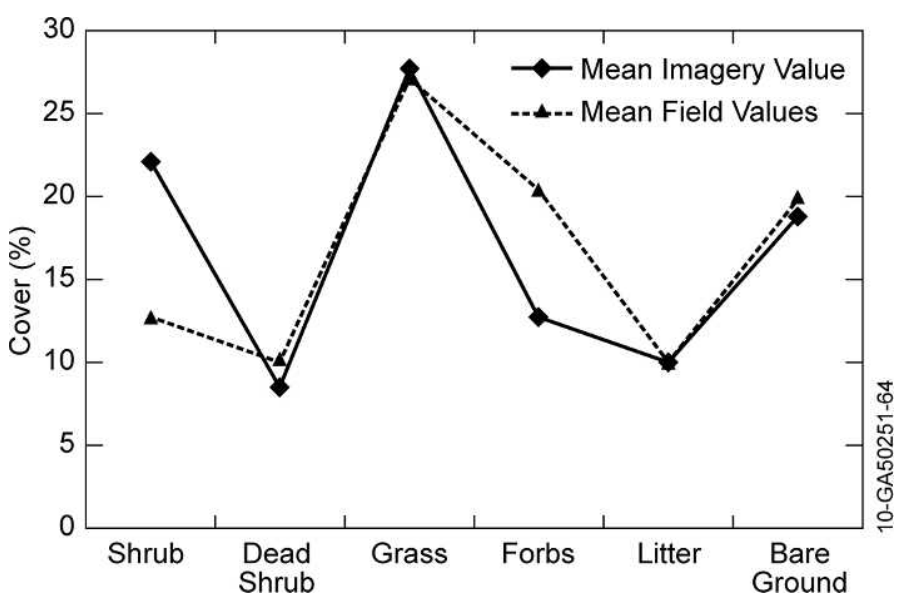

Figure 4. Comparison of imagery values against field values for July helicopter data flown at $\approx 11 \mathrm{~m} \mathrm{AGL}$. 


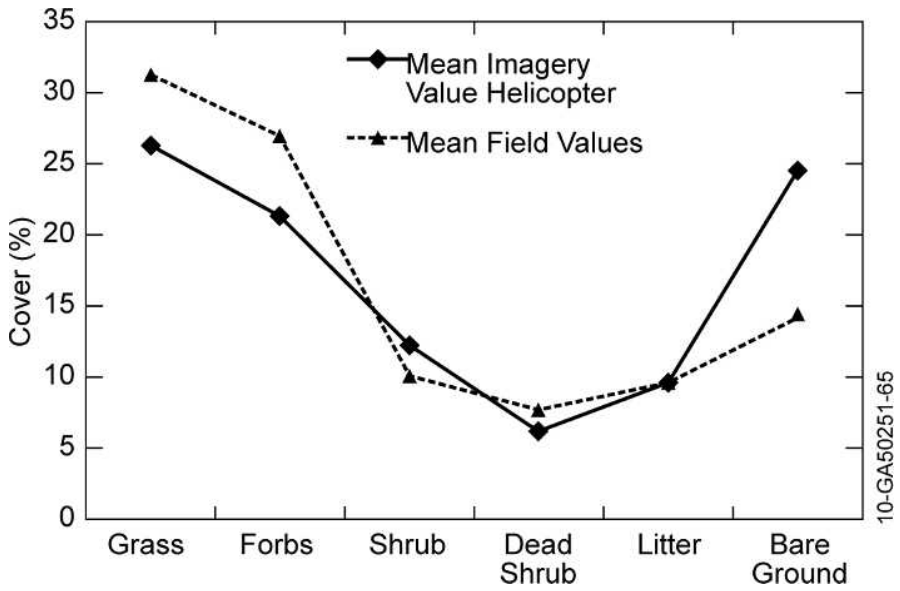

Figure 5. Comparison of imagery values against field values for June helicopter data flown at $\approx 11 \mathrm{~m}$ AGL. Note: Field values were collected in July.

The helicopter imagery collected in June 2005 showed patterns similar to those for the July 2005 imagery and field data (see Fig. 5). Much of the difference between the field and imagery values may be attributed to the fact that the field values were collected more than a month after the imagery values and the plants had not reached their peak growth period in early June 2005. Results support this idea because the imagery values tend to classify more areas as bare ground when the field assessment shows it to be grass or forbs. In Figure 5, the difference between these estimates was significant only for bare ground $(P=0.037)$, although the difference for forbs was marginally significant $(P=0.073)$.

This study has identified some of the limitations of using UAV technology for the evaluation of shrubs and forbs and the possible advantage of the technology for the evaluation of litter, grass, and bare ground. The remote sampling approach using a near-earth UAV platform may be best for collecting large random samples for rangeland assessments. Until more experience exists comparing UAV and field data (Rango 2009), on-the-ground quality checks should be conducted to verify accuracy.

Comparison of Time Required for Data Collection and Analysis The time required to collect and process all field plots using the UAV approach was about 32 person-hours for seven plots. The field method required 72 person-hours to sample only $50 \%$ of the field subplots. Thus, the UAV method took about $45 \%$ of the time if $50 \%$ of the subplots were read and $22 \%$ of the time if all subplots were read using both methods. (These times do not include training time.) The time for field data collection could in general be reduced by experienced field crews, but it would be almost impossible to reduce the time to below that required to collect the imagery with the helicopters.

In conclusion, the study shows that UAVs are a feasible platform for collecting data for conducting rangeland assessments. Second, UAVs hold promise for collecting imagery to measure selected cover classes (i.e., grass, litter, and bare ground). Third, under the constraints of this study, UAV technology, compared to field methods, requires a lower number of labor hours per plot and produces a reliable digital data record. However, there are up-front costs in establishing a UAV system for the aerial platform and purchasing a camera and image-processing software. One advantage of conducting this research at a national laboratory was that all of the equipment was available because it belonged to other programs. The cost of the system used in this study was about $\$ 5,000$.

Two things will influence the future use of unmanned helicopters: 1) improved technology will continue to decrease equipment weight and increase data storage capacity (including the helicopter platform, camera system, and image-processing systems), and 2) high-quality, reliable data will be required for making and defending management decisions. Considering these factors, along with the concerns of safety, increasing costs for fieldworkers, and reduced availability of experienced field specialists; UAV helicopters may provide cost-effective options for collecting data for rangeland management.

We developed four recommendations based on the results of this study. First, UAV helicopters provide an excellent platform for collecting small samples over fairly large areas but have limitations on how long they can fly. Also, flying UAV helicopters requires advanced UAV-flying skills. Second, determining the optimum height AGL for conducting UAV flights is critical for making observations as quickly as possible. Flights conducted at higher levels can collect imagery for a larger area, but resolution is reduced. Third, image-processing using SamplePoint was very useful for this study. However, for UAV helicopters or any other near-earth image collection system to become more useful, image-processing software needs to be automated and reliable. Fourth, this work was originally conducted in the field season of 2005 and at the time showed promise for measurement of bare ground, a key rangeland indicator. Since that time, there have been a number of advances that have occurred in UAV technology, computer analysis equipment, and cameras that would warrant the study to be revisited. The study design and analysis approach used here could be applied to a revised study.

\section{MANAGEMENT IMPLICATIONS}

Depending on land management objectives, managers should consider the results from this study as a possible future method for collecting vegetation data using UAV helicopters. These platforms can fill an important niche between the fieldworker and remote imagery from planes and satellite systems. They are highly mobile, can cover large areas of rangelands, involve relatively low safety risk with proper training, and reduce the time spent in the field collecting data. This technology does require an investment in equipment and software and requires staff to haul additional equipment (i.e., UAV, fuel, landing mat, and so on) to a field site.

Managers and rangeland scientists from the BLM, USDA Forest Service, and the National Park Service should evaluate the results presented here and determine if they provide adequate data to meet management objectives. Greater involvement with land management agency scientists will improve the understanding of the current challenges and will 
enhance data collection, which should make the data better accepted by the agencies. Using results from this study, land managers of semiarid ecosystems could consider using UAV platforms to collect data for selected vegetation classes. Because there appears to be convergence in the scientific community (Pellant et al. 2005) that bare ground is one of the most important vegetation cover measurements for assessing rangeland health, UAV platforms may play an important role in securing quality information for future resource inventory and monitoring activities (Breckenridge and Dakins 2011).

\section{ACKNOWLEDGMENTS}

The authors would like to extend sincere thanks to Mark McKay for piloting the helicopter; Ron Rope, Ryan Hruska, Sera White, and Angie Smith (INL); Marilynne Manguba (The Nature Conservancy); Anthony Piscitella, Chase Eckersell, and Katherine Schoellenbach (students) for assistance in collecting field data, reading imagery, and assisting with edits; Terry Booth and Sam Cox (USDA-ARS) for developing and assisting with SamplePoint; Dr Larry Blackwood for providing guidance with statistical analysis; and Drs Lee Vierling and Don Crawford (University of Idaho) and Sue Vilord, Jackie Hafla, and Roger Blew (Gonzales-Stoller Surveillance, LLC) for technical guidance and assistance with providing equipment and quality control checks for field activities.

\section{LITERATURE CITED}

Anderson, J. E., K. T. Ruppel, J. M. Glennon, K. E. Holte, and R. C. Rope. 1996. Plant communities, ethnoecology, and flora of the Idaho National Engineering Laboratory. Idaho Falls, ID, USA: Environmental Science and Research Foundation. ESRF-005. 110 p.

Blackwood, L. C., and E. L. Bradley. 1991. An omnibus test for comparing two measuring devices. Journal of Quality Technology 23:12-16.

BonHam, C. D. 1989. Measurements for terrestrial vegetation. New York, NY, USA: John Wiley \& Sons. $319 p$.

Booth, D. T., S. E. Cox, and R. D. Berryman. 2006a. Point sampling digital imagery with "SamplePoint." Environmental Monitoring and Assessment 123:97-108.

Booth, D. T., S. E. Cox, T. W. Meikle, and C. Fitzgerald. 2006b. The accuracy of ground-cover measurements. Rangeland Ecology \& Management 59:179-188.

Booth, D. T., AND P. T. Tueller. 2003. Rangeland monitoring using remote sensing. Arid Land Research and Management 17:455-467.

BreCKeNRIDGE, R. P. 2007. Improving rangeland monitoring and assessment: Integrating remote sensing, GIS and unmanned aerial vehicle systems [thesis] Moscow, ID, USA: University of Idaho. $121 \mathrm{p}$.

BreCKeNRIDGE, R. P., AND M. E. Dakins. 2011. Evaluating of bare ground on rangelands using unmanned aerial vehicles: a case study. G/Science \& Remote Sensing 48:74-85.

Brower, J. E., J. H. Zar, and C. N. Von EndE. 1990. Field and laboratory methods for general ecology. 3rd ed. Dubuque, IA, USA: Wm C. Brown Publishers. $237 \mathrm{p}$.

Brown, D. E. [ED.]. 1982. Biotic communities of the American Southwest-United States and Mexico. Desert Plants 4:1-344.

BuntiNG, S. C. 2002. Natural and prescribed fires in big sagebrush steppe-response of individual species and implication to burning practices. Restoration and Management of Sagebrush/Grass Communities Workshop; 4-8 November 2002; Elko, NV, USA. Elko, NV, USA: RangeNet. 54 p. Available at: http://www. rangenet.org/trader/2002_Elko_Sagebrush_Conf.pdf. Accessed 23 May 2012.

Bunting, S. C., B. M. KILgoRE, AND C. L. Bushey. 1987. Guidelines for prescribed burning sagebrush-grass rangelands in the northern Great Basin. Ogden, UT, USA: USDA Forest Service Rocky Mountain Research Station. General Technical Report INT231. 33 p. Available at: http://www.fs.fed.us/rm/pubs_int/int_gtr231.pdf. Accessed 5 September 2010.
Carroll, C. R., J. Belnap, R. Breckenridge, and G. Meffe. 1999. Ecosystem sustainability and condition. In: W. T. Sexton, A. J. Malk, R. C. Szaro, and N. C. Johnson [EDS.]. A common reference for ecosystem management. Volume 2. New York, NY, USA: Elsevier Science. p. 583-598.

Colket, E. C. 2003. Long-term vegetation dynamics and post-fire establishment patterns of sagebrush steppe [thesis]. Moscow, ID, USA: University of Idaho. $144 \mathrm{p}$.

Connelly, J. W., K. P. Reese, R. A. Fischer, and W. L. Wakkinen. 2000. Response of a sage grouse breeding population to fire in southeastern Idaho. Wildlife Society Bulletin 28:90-96.

Cook, C. W., AND J. StuBBendeCK. 1986. Range research: basic problems and techniques. Denver, CO, USA: Society for Range Management. $317 \mathrm{p}$.

Crawford, J. A., R. A. Olson, N. E. West, J. C. Mosley, M. A. Schroeder, T. D. Whitson, R. F. Mlller, M. A. GregG, and C. S. Boyd. 2004. Ecology and management of sage-grouse and sage-grouse habitat. Journal of Range Management 57:2-19.

Daubenmire, R. F. 1970. Steppe vegetation of Washington. Pullman, WA, USA: Washington State University, Agricultural Experiment Station. Technical Bulletin 62. $131 \mathrm{p}$

[FAA] Federal Aviation Administration. 2008. Interim operational approval guidance 0801: unmanned aircraft systems operations in the U.S. national airspace system. Washington, DC, USA: Aviation Safety Unmanned Aircraft Program Office. AIR160. $18 \mathrm{p}$.

Floyd, D. A., And J. E. Anderson. 1982. A new point frame for estimating cover of vegetation. Vegetatio 50:185-186.

Forman, A. D., AND J. R. HafLA. 2009. Common plants of the INL. Idaho Falls, ID, USA: Environmental Surveillance, Education and Research Program. STOLLER-ESER81. 134 p. Available at: http://www.gsseser.com/PDF/Handbook2009.pdf. Accessed 23 May 2012.

Gatens, K. 2010. UAVs take flight over Idaho. Available at: https://inlportal.inl.gov/ portal/server.pt/community/robotics_and_intelligence_systems/455/uavs_take_ flight_over_idaho/6130. Accessed 23 May 2012.

GruBBS, F. E. 1973. Errors of measurement, precision, accuracy and the statistical comparison of measuring instruments. Technometrics 15:53-66.

Hardin, P. J., M. W. Jackson, V. J. Anderson, and R. Johnson. 2007. Detecting squarrose knapweed (Centaurea virgata Lam. Ssp. squarrosa Gugl.) using a remotely piloted vehicle: a Utah case study. GIScience and Remote Sensing 44:203-219.

Johnson, D. E., M. Vulfson, M. Louhaichi, and N. R. HarRis. 2003. VegMeasure version 1.6 user's manual. Corvallis, OR, USA: Oregon State University, Department of Rangeland Resources, VegMeasure Project. $51 \mathrm{p}$.

KeELEY, J. E. 2006. Fire management impacts on invasive plants in the western United States. Conservation Biology 20:375-384.

KNICK, S. T., AND J. T. RotenBerRy. 1995. Landscape characteristics of fragmented shrubsteppe habitats and breeding passerine birds. Conservation Biology 9:1059-1071.

Maczko, K. A., L. D. Bryant, D. W. Thompson, and S. J. Borchard. 2004. Putting the pieces together: assessing social, ecological, and economic rangeland sustainability. Rangelands 26(3):3-14.

Mahalovich, M. F., and E. D. McArthur. 2004. Sagebrush seed (Artemisia ssp.) and plant transfer guidelines. Native Plants 5:141-148.

Mouat, D. A., and C. F. Hutchinson [EDS.]. 1995. Desertification in developed countries. Dordrecht, The Netherlands: Kluwer Academic Publishers. $363 \mathrm{p}$.

National Research Council. 1994. Rangeland health: new methods to classify, inventory, and monitor rangelands. Washington, DC, USA: Committee on Rangeland Classification, National Academies Press. $180 \mathrm{p}$

National Transportation Safety Board. 2010. Aviation accident database \& synopses. Available at: http://www.ntsb.gov/investigations/reports_aviation.html. Accessed 23 May 2012.

Pedersen, E. K., J. W. Connelly, J. R. Hendrickson, and W. E. Grant. 2003. Effect of sheep grazing and fire on sage grouse populations in southeastern Idaho. Ecological Modelling 165:23-47.

Pellant, M., P. Shaver, D. A. Pyke, and J. E. Herrick. 2005. Interpreting indicators of rangeland health. Version 4. Denver, CO, USA: US Department of the InteriorBureau of Land Management National Science and Technology Center. Technical Reference 1734-6, BLM/WO/ST-00/001+1734/REV05. 122 p. Available at: http://www.blm.gov/nstc/library/pdf/1734-6rev05.pdf. Accessed 23 May 2012. 
Pitman, E. J. G. 1939. A note on normal correlation. Biometrics 31:9-12.

Pyke, D. A., J. E. Herrick, P. Shaver, and M. Pellant. 2002. Rangeland health attributes and indicators for qualitative assessment. Journal of Range Management 55:584-597.

Rango, L. A., A. Laliberte, J. E. Herrick, C. Winters, K. Havstad, C. Steele, and D. Browning. 2009. Unmanned aerial vehicle-based remote sensing for rangeland assessments, monitoring and management. Journal of Applied Remote Sensing 3:1-15.

Rickard, W. H., L. E. Rogers, B. E. Vaughan, and S. F. Liebetrau [eds.]. 1988. Shrubsteppe: balance and change in a semi-arid terrestrial ecosystem. New York, NY, USA: Elsevier. $272 \mathrm{p}$.

Sмiтt, R. L. 1990. Ecology and field biology. 4th ed. New York, NY, USA: HarperCollins. $922 \mathrm{p}$.

Society for Range Management, Task Group on Unity in Concepts and Terminology Committee Members. 1995. New concepts for assessment of rangeland condition. Journal of Range Management 48:271-282.
[USDI-BLM] US Department of the Interior-Bureau of Land Management. 1997. Standards for healthy rangelands and guidelines for livestock grazing management for the public lands administered by the Bureau of Land Management in the State of Wyoming. Cheyenne, WY, USA: US Department of the Interior-Bureau of Land Management Wyoming State Office. Booklet BLM/ WY/AE-97-023+1020. 16 p. Available at: http://www.blm.gov/wy/st/en/ programs/grazing/standards_and_guidelines.html. Accessed 23 May 2012.

WALKER, B. H. 1993. Rangeland ecology: understanding and managing change. AMBIO 22:80-87.

WhitFoRD, W. G. [ED.]. 1986. Pattern and process in desert ecosystems. Albuquerque, NM, USA: University of New Mexico Press. $139 p$.

ZAGER, P. 2006. UAVs and natural resources. Eleventh Biennial USDA Forest Service Remote Sensing Applications Conference; 24-28 April 2006; Salt Lake City, UT, USA. Salt Lake City, UT, USA: USDA Forest Service Remote Sensing Applications Center. 33 p. Available at: http://www.fs.fed.us/eng/rsac/RS2006/presentations/ zager.pdf. Accessed 23 May 2012. 